\title{
PRODUCTION RESULTS OF ALPINA GOATS FARM IN THE ZLETOVO REGION, NORTH MACEDONIA
}

\author{
Elena Eftimova, Nikola Pacinovski, Nataša Mateva-Dubrova, Nedeljka Nikolova, Ana Palaševska \\ Institute of Animal Science, Ss. Cyril and Methodius University in Skopje, \\ Blvd. Ilinden 92a, Skopje, Republic of North Macedonia \\ eleef68@yahoo.com
}

\begin{abstract}
A b s t r a c t: The role of goats in world livestock is significant and there is not a country in wich they are not bred. The goat production in the Republic of North Macedonia is characterized by spontaneous and continuous development, and with each day there is greater interest of farmers for breeding goats as a business that provides secure existence and profit.The aim of the research within this study was to assess productive characteristics of conventional goat farm operating in the Zletovo region. The researches lasted 3 years $(2008,2009$ and 2010) at the farm where around 100-120 heads of goats of all categories of the Alpine race are bred. Almost the whole milk produced at the farm is processed into dairy products such as: white brined cheese and cashkawall. The kids born there are used as kids for market of livestock products, kids sold as breeding goats and part of them are retained for own reproduction in the herd. The percentage of fertility was the highest in $2010(125.32 \%)$, in 2009 was $122.99 \%$ and in 2008 was $118.99 \%$. The percentage of conception was the higest in 2009 (90.63\%), in 2008 was $87.78 \%$ and in 2010 was $82.29 \%$. The average lactation length in 2008 was 258.3 days, in 2009 was 265.4 days, and in 2010 was 261.7 days. The average daily amount of milk production in 2008 was 0.93 liters, in 2009 was 0.96 liters, and in 2010 was 1.01 liters per head. The average milk yield in 2008 was 241.23 liters, in 2009 was 251.47 liters, and in 2010 was 263.57 liters. The farm worked with profit in all three years of research.
\end{abstract}

Key words: goats of alpine breed; milk; kids

\section{ПРОИЗВОДНИ РЕЗУЛТАТИ ОД ОДГЛЕДУВАЊЕЊТО НА КОЗИ ОД РАСАТА АЛПИНА ВО РЕГИОНОТ НА ЗЛЕТОВО, СЕВЕРНА МАКЕДОНИЈА}

А п с т р а к т: Улогата на козите во сточарството во светот е значајна и не постои земја во која тие не се одгледуваат. Производството на кози во Република Северна Македонија се карактеризира со спонтан и континуиран развој, а секој ден се зголемува интересот на фармерите за одгледување кози како бизнис кој обезбедува сигурна егзистенција и добивка. Целта на истражувањето во рамките на оваа студија беше да се проценат продуктивните карактеристики на конвенционалната фарма за одгледување кози во злетовскиот регион. Истражувањата траеја 3 години $(2008,2009$ и 2010) на фарма на која што се одгледуваат околу 100-120 грла од сите категории кози од расата алпина. Речиси целото млеко произведено на фармата се преработува во млечни производи како што се бело саламурено сирење и кашкавал. Јарињата родени таму се користат за пазарот на сточарски производи, за продавање како грла за приплод и дел од нив се задржуваат за сопствена репродукција на стадото. Процентот на плодност беше највисок во 2010 година $(125,32 \%)$, во 2009 година беше 122,99\% и во 2008 година беше 118,99\%. Процентот на концепција беше најголем во 2009 година (90,63\%), во 2008 година беше $87,78 \%$ и во 2010 година беше $82,29 \%$. Просечното времетраење на лактацијата во 2008 година беше 258,3 дена, во 2009 година 265,4 дена, а во 2010 година 261,7 дена. Просечното дневно производство на млеко во 2008 година изнесуваше 0,93 литри, во 2009 година 0,96 литри, додека во 2010 година 1,01 литри по грло. Просечниот годишен принос на млеко по грло во 2008 година беше 241,23 литри, во 2009 година 251,47 литри, а во 2010 година 263,57 литри. Во сите три години на истражувањето фармата работеше со добивка. 


\section{INTRODUCTION}

In the livestock world the role of goats is significant and almost there is no country in the world in which they are not bred. Prevelance of goats is due to their good capacity to acclimatize in various climatic and environmental conditions and for the production of milk, meat and leather at low production price. The goat production in the Republic of North Macedonia is characterized by spontaneous and continuous development, and each day there is a greater interest of farmers for breeding goats as a business that provides secure existence and profit.

According to the FAO data [14], the number of goats in the Republic of North Macedonia is about 107466. The breed composition of goats in the country is based on the domestic Balkan goat with a certain representation of the Alpine breed goats, Saanen and crossbreds of these races.

Basic product obtained from goats is goat's milk (which is commonly processed into white brined cheese) and kids and goat meat.

The purpose of this research is to show relevant data for production indicators of conventional goat farm where goats of Alpine race are bred.

The farm worked with profit in all three years of research. The results show that goat breeding in the Republic of North Macedonia has opportunities for further development.

\section{MATERIALS AND METHODS}

The survey was conducted at the goat farm in the village of Zletovo, Probištip region, where about 100-120 goats of the Alpine race were bred within 3 years (2008, 2009 and 2010).

The breeding system is in barn and on pasture breeding, and the produced quantity of milk is processed in several product types in the dairy within the farm (white brined cheese and curd). The kids born there are used for herd self-reproduction, sold as breeding material, and also as kids intended for the livestock products market. The nutrition of the goats did not deviate from the usual practice and it was in accordance with the breeding phases during the year. Used feed is of organic origin (alfalfa, pea, vetchling and barleycorn), and the goats were pastured on certified organic pastures. The assigned veterinary, sanitary and zootechnical measures are fully implemented at the farm.

Production results monitoring was conducted by continuous collecting, recording and processing of milk and goat production data during whole research period. The lactation control was carried out with $\mathrm{A}_{4}$ method [4]. The kids production included monitoring of multiple parameters as: total number and gender of the born kids, number of: dead kids, sold kids and kids left for self reproduction.

The obtained results were statistically processed according to the Fisher method (F-test) on the level of probability of $P<0.05, P<0.01$ and $P<0.001$ [2].

\section{RESULTS AND DISCUSSION}

The average age of milking goats in 2008 was 3.3 years, while of the whole herd 2.7 years. In 2009 it was 3.2 years and 2.8 years, while in 2010 it was 3.2 and 3.1 years, respectively. ble 1.

Milk production at the farm is presented in Ta-

Table 1

Milk production at the farm
in 2008, 2009 and 2010

\begin{tabular}{|c|c|c|c|c|}
\hline \multirow{2}{*}{ Parameter } & \multicolumn{3}{|c|}{ Year } & \multirow{2}{*}{ Average } \\
\hline & 2008 & 2009 & 2010 & \\
\hline $\begin{array}{l}\text { Lactation lenght } \\
\text { (days) }\end{array}$ & 258.30 & $265.40 * * *$ & 261.70 & 261,80 \\
\hline $\begin{array}{l}\text { Daily milk yield } \\
\text { (liters/day) }\end{array}$ & 0.93 & 0.96 & 1.01 & 0,97 \\
\hline Milk yield (liters) & 241.23 & $251.47 * * *$ & $263.57 * * *$ & 252,09 \\
\hline
\end{tabular}

${ }^{\mathrm{ns}} P>0.05, * P<0.05, * * P<0.01, * * * P<0.001$

Obtained results of the average length of lactation (258.30 (min. 198, max. 279); 265.40 (min. 215, max.311); and 261.70 (min. 238, max. 304)) compared to the data obtained in the Croatian Livestock Center in 2008 (259 days) as well as by Mioč et al. [9] (2007 - 259 days), Kompan et al. (1998) (citation by Andonov [1]) - 258 days), and Memiši et al. [8] (2011 - 252 days) the variations from 202 to 302 days are very close.

While testing the variations regarding the lactation length between 2008 and 2009 at this farm, statistical importance on level $P<0.001$ was confirmed. The variations regarding the lactation length between 2008 and 2010 and between 2009 and 2010 had no significant value $(P>0.05)$.

The average lactation yield in 2008 was 241.23 liters (min. 98.78, max. 368.25), in 2009251.47 liters (min. 112.58, max. 427.65), and 263.57 (min. 
128.42, max. 458.72) liters in 2010. Obtained results of the average lactation were reported by Žujović et al. [13]: (489.52 kg in 2008; $498.59 \mathrm{~kg}$ in 2009 and $465.18 \mathrm{~kg}$ in 2010) and thay are very higer. Approximate results were reported by Pavliček et al. [10]: 288.26 liters at goats in the first lactation.

While testing the variations regarding the lactation between 2008 and 2010, and between 2009 and 2010 at this farm, statistical significance on level $P<0.001$ was confirmed. The variation in the lactation at this farm between 2008 and 2009 had no significant value $(P>0.05)$.

The obtained results of average daily milk yield at the farm during the study $(0.93,0.96$ and 1.01 liters) are lower than the results obtained by Memiši et al. [8], which amounted to 1.24 liters at goats in the first lactation, $1.4 \mathrm{~kg}$ at goats in the second lactation, 1.49 liters in the third and 1.52 liters in the fourth lactation, and by Martina Herceg [3] (2010) which amounted to 2,08 liters.

Anyway, during the following years is expected increasing of milk production at the farm because of the fact that the goats which are bred during the researching period were in the first and second lactations, and according Antunac (1994) (cited by Pavliček [10]), Margetin and Milerski (2000) (cited by Pavliček [10]), Andonov et al. [1], Herceg [3] and Mekić et al. [7] (2010), the milk production of the goats increases with increasing the number of lactations in sequence.

Kids' production is presented in Table 2.

According to data in Table 2, in 2008 at the farm were born 94 kids, of which $57.45 \%$ are female and $42.55 \%$ male. Of them, $68.32 \%$ were born as twins. The farmer kept 20 kids $(21.23 \%)$ for herd self-reproduction.

In 2009, from the total number of kids (107), $45.79 \%$ were born as female, while $54.21 \%$ as male kids. The percentage of the twins was $62.62 \%$, while the percentage of mortality was $10.28 \%$. Of the total number of kids raised, $20.83 \%$ were kept by the farmer for self reproduction.

In 2010, 99 kids were born at the farm, of which $43.43 \%$ were born as female, while $56.57 \%$ as male kids. The percentage of the twins was $52.53 \%$. This year, the percentage of mortality was $3.03 \%$. In 2010, the farmer kept 9 female kids for herd self-reproduction.

The percentage of twins confirmed by Vnučec et al. [12], which is $54.84 \%$, is significantly lower than the values obtained in this survey.

Table 2

Kid's production (\%)

\begin{tabular}{lcccc}
\hline \hline \multirow{2}{*}{ Kids } & \multicolumn{3}{c}{ Year } \\
& 2008 & 2009 & 2010 \\
\hline Live born & 94 & 107 & 99 \\
- female kids & 54 & 49 & 43 \\
- male kids & 40 & 58 & 56 \\
Dead after birth & 5 & 7 & 3 \\
Dead during the year & 4 & 4 & $/$ \\
Bred kids & 85 & 96 & 96 \\
Twin kids & 30 & 40 & 52 \\
Sold for meat & 58 & 66 & 78 \\
Sold for breeding & 7 & 10 & 8 \\
Left for reproduction & 20 & 20 & 10 \\
- male kids & $/$ & $/$ & 1 \\
- female kids & 20 & 20 & 9 \\
\hline \hline
\end{tabular}

The percentages of fertility, conception and sterility in 2008, 2009 and 2010 are presented in Figure 1.

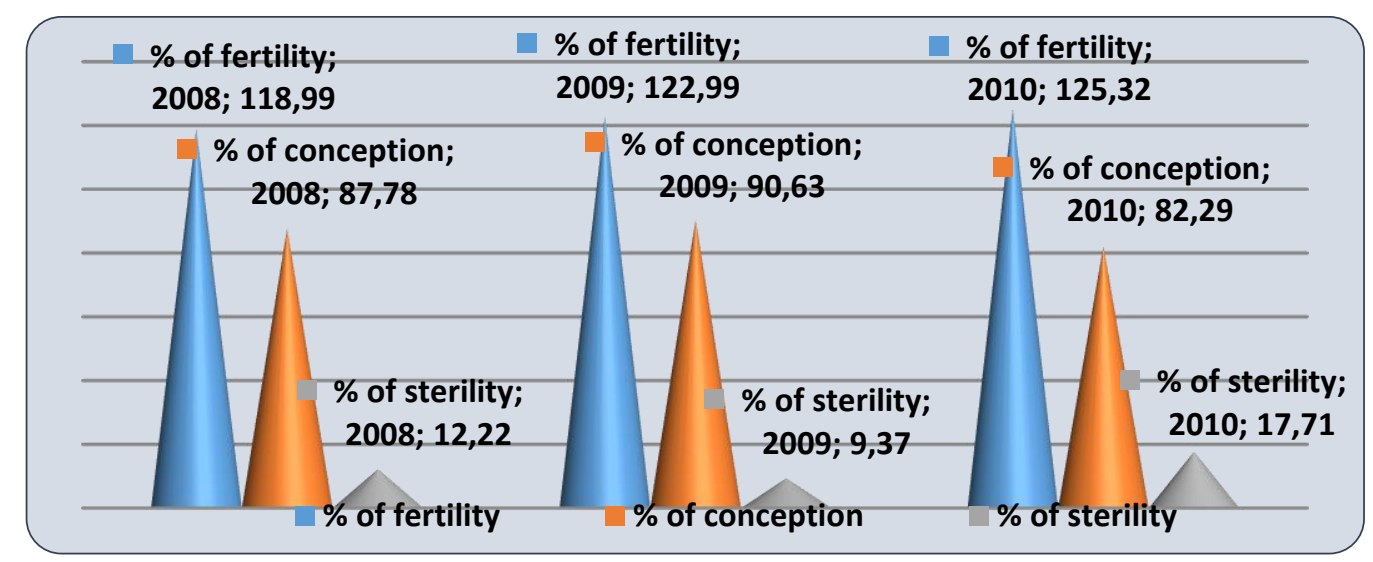

Fig. 1. Percentage of fertility, conception and sterility 
Results of the fertility of goats in this study compared to the results of Mekić et al. (2010), according to which the fertility of goats of the Alpine race during the first year is about $130 \%$, and later it increases, are very similar. At the same time, Vnučec et al. (2005) found higher fertility than the obtained (159.1\%) in goats of Alpine breed grown in Croatia.

\section{CONCLUSIONS}

On the basis of the gained results from the analysis of the productive traits of the Alpina goat, the following conclusions can be taken:

1) The average lactation length expressed in days was 258.30 days in 2008; 265.40 days in 2009; while in 2010 it was 261.70 days.

2) The average milk yield was 241.23 liters in 2008; 251.47 liters in 2009; and 263.57 liters in 2010.

3) The average daily milk yield in 2008 was 0.93 liters; in 2009 it was $0.96 \mathrm{~L}$; while in 2010 1.01 liter.

4) The percentages of fertility in 2008 was $118.99 \%$, in 2009 was $122.99 \%$, and in 2010 was $125.32 \%$

5) The percentages of conception in 2008 was $87.78 \%$, in 2009 was $90.63 \%$, and in 2010 was $82.29 \%$

6) The percentages of sterility in 2008 was $12.22 \%$, in 2009 was $9.37 \%$, and in 2010 was $17.71 \%$

\section{REFERENCES}

[1] Andonov S., Kovac M., Kompan D. (1995): BLUP estimation of breeding values for daily milk yield and fat content in dairy goats. 3 KOK. 5-9 Sep., Ohrid, pp. 198-208.
[2] Hadživuković S., Čobanović K. (1994): Statistika: principi $i$ primena. Monografija. Poljoprivredni fakultet, Univerzitet u Novom Sadu.

[3] Herceg M. (2010): Utjecaj pasmine i redoslijeda laktacije na mliječnost koza u Hrvatskoj. Diplomski rad, Agroekonomski fakultet, Sveučilište u Zagrebu (www.htpp://bib. irb.hr). Accessed, 01.10.2010.

[4] ICAR (2012): International agreement on recording practices. Approved June 2012, Cork, Ireland.

[5] Krstić, B., Lučić Đ. (2000): Organizacija i ekonomika proizvodnje i prerade stočnih proizvoda. Udžbenik. Poljoprivredni fakultet, Novi Sad, Serbia.

[6] Мартиновска-Стојчевска, А. (2007): Трошоичиеие и кал-

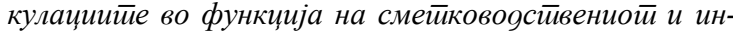
формациониой систием на иноивияуалните земјооелски сииойансиива. Докторска дисертација, Факултет за земјоделски науки и храна, Скоопје, Македонија.

[7] Mekić C., Trifunović G., Novaković Z. (2010): Specifičnosti, osobine kozjeg mleka i perspektive intenzivne proizvodnje (farme mlečnih koza). Agrosym. Jahorina, pp. 124132.

[8] Memiši N., Bogdanović V., Žujović M., Tomić Z. (2011): Influence of order of lactation on milk production and somatic cell count in Alpine goats. Biotechnology in Animal Husbandry, 27 (2), pp. 227-234.

[9] Mioč, B., Pavić, V., Barać, Z., Prpić, Z, Vnučec, I. (2007): Mliječnost nekih pasmina koza u Hrvatskoj. Mljekarstvo, 57 (1), pp. 67-77.

[10] Pavliček, J., Antunović Z., Senčić Đ., Šperanda, M.. (2006): Proizvodnja i kemiski sastav kozjeg mleka u ovisnosti o redosledu i stadiju laktacije. Scientific and Professional Review, Vol. 12, No. 2, pp. 52-57.

[11] Skalički, Z., Urošević, M., Ostojić, M., Mekić, C. (1998): Proizvodnja mleka francuske alpske rase koza. Arhiv za poljoprivredne nauke, 59, (1-2), 208, pp. 17-22.

[12] Vnučec, I., Mioč, B., Pavić, V., Kapš, M. (2009): Plodnost koza i prirast jaradi u intenzivnim uvjetima proizvodnje. XL Znanstveni skup hrvatskih agronoma, Zbornik radova pp. 647-648.

[13] Žujović, M., Memiši, N., Ivanović, S. (2011): Present status, possibilities and perspective of development of goat production in Republic of Serbia. Biotechnology in Animal Husbandry 27 (3), pp. 431-443.

[14] http://faostat.fao.org/site/573/DesktopDefault.aspx?Page ID=573\#ancor

[15] http://www.mzsv.gov.mk/Tabela\%20organsko.pdf.. 